\title{
Water on the Fen Mire as a Problem in the Protection of Globally Threatened Species: Long-Term Changes in Aquatic Warbler Numbers
}

\author{
Grzegorz Grzywaczewski ${ }^{1}$, Andrzej Bochniak², Jarosław Wiącek³, \\ Pawel Lapiński ${ }^{4}$, Federico Morelli ${ }^{5,6}$
}
${ }^{1}$ University of Life Sciences in Lublin, Department of Zoology, Animal Ecology, and Wildlife Management, Akademicka 13, PL-20-950 Lublin, Poland
${ }^{2}$ University of Life Sciences in Lublin, Department of Applied Mathematics and Computer Science,
Głęboka 28, PL-20-950 Lublin, Poland

${ }^{3}$ Maria Curie-Skłodowska University, Biology and Biochemistry Institute, Department of Nature Conservation, Akademicka 19, PL-20-033 Lublin, Poland

${ }^{4}$ The State School of Higher Education in Chełm, Pocztowa 54, PL-22-100 Chełm, Poland

${ }^{5}$ Faculty of Biological Sciences, University of Zielona Góra, Institute of Biotechnology and Environmental Protection, Prof. Szafran St. 1, PL 65-516 Zielona Góra, Poland

${ }^{6}$ Czech University of Life Sciences Prague, Faculty of Environmental Sciences,

Department of Applied Geoinformatics and Spatial Planning,

Kamýcká 129, CZ-165 00 Prague 6, Czech Republic

Received: 6 June 2016

Accepted: 20 September 2016

\begin{abstract}
This paper presents the results of 11 years study of aquatic warblers in the Roskosz Nature Reserve in eastern Poland. The study was carried out in fen mires near Chełm, in the proximity of the Polish-Ukrainian boundary. The number of aquatic warblers was correlated with the mean water level and with the mean groundwater level. We found that the higher the surface water level, the smaller the number of singing males. The largest number of males (density 10.9 singing males per 10 ha) was found when the mean water level was $23.7 \mathrm{~cm}$, and the smallest number (density 2.1 singing males per $10 \mathrm{ha}$ ) when the mean water level was $35.7 \mathrm{~cm}$. These results can be useful in studies that focus on the optimal habitat conditions for breeding of aquatic warblers. This is the first systematic study in calcareous Cladium mariscus fen mires.
\end{abstract}

Keywords: aquatic warbler, Acrocephalus paludicola, fen mires, water level, ecology of wetland birds

*e-mail: grzegorz.grzywaczewski@up.lublin.pl 


\section{Introduction}

The aquatic warbler (AW) Acrocephalus paludicola is the rarest migratory bird in Europe. Globally threatened (VU: vulnerable in the Red Data Book category), the species is running a fairly high risk of extinction [1]. Worldwide, AW is known to reproduce in only 40 localities situated across six countries. About $90-95 \%$ of the world population, estimated at 10,500-14,200 singing males $(\widehat{\jmath})$ is located in Belarus, Ukraine, and Poland [2]. More than $90 \%$ of the Polish population sits in two areas: Biebrza valley $(2,761 \hat{\jmath}$, or $22 \%$ of the world population) and the

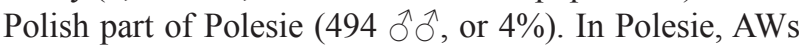
breed above all in Polesie National Park (297 §ิ ठิ, 2.4\% of the world population) and on the fen mires near Chełm (195 $\hat{\jmath}, 1.6 \%$ ). Because the fen mires near Chełm are home to $>1 \%$ of the world population, monitoring areas have been set up there, inter alia in the Roskosz Nature Reserve [2-5].

AW feed on relatively large invertebrates, in contrast to related species like the sedge warbler Acrocephalus schoenobaenus [6]. Preferred sites of occurrence are sedge, fen mires, Cladium mariscus marshes, and wet sedge meadows in river valleys [2]. They inhabit natural fen mires or similar habitats as eutrophic and mesotrophic river valleys [7-9]. They prefer an environment with the sedge Carex sp. up to $80 \mathrm{~cm}$ tall and no more than a few $\mathrm{cm}$ of water [3]. The most important threats are loss of breeding habitat owing to drainage for agriculture and peat extraction, damming of floodplains, unfavourable water management, and the canalization of rivers [10].

Studies of the AW's habitat conditions have indicated that water level is one of the main factors governing the presence of this species $[2-3,7]$. The density of singing AW males is a good indicator of the density of females as the higher density of males also means a higher density of females. But densities are influenced by water level because when the water level is too high (above $20 \mathrm{~cm}$ ), females do not build nests $[3,7,11]$. Water affects the accessibility of nests to predators, the composition and abundance of food resources, and, hence, breeding success [3, $7,11]$. Although AW has been the object of a many investigations during the last 20 years [7, 11-20], the relevant literature does not boast a set of long-term data gathered every year on the same area, especially in the context of water-level changes. In fact, even though these studies could have great importance for the conservation planning of the species in Europe, the analysis of such long-term data on changes in AW numbers and water-level records is a problem that has yet to be addressed. A study on habitat parameters in Cladium fen mires is a new aspect not yet published.

The main objective of this study was to assess the longterm changes in AW numbers in relationship to changes in the water level. This is the first systematic study in calcareous Cladium mariscus fen mires.

\section{Materials and Methods}

The study was carried out in Roskosz Nature Reserve (N51 ${ }^{\circ} 08^{\prime} 41^{\prime \prime}, \mathrm{E} 23^{\circ} 39^{\prime} 38^{\prime \prime} ; 473$ ha) over a period of 11 years (2004-14). Counting of singing males was carried out on a survey plot (area $182 \mathrm{ha}$ ). The survey plot was set up in a marshland complex situated in eastern Poland, about $15 \mathrm{~km}$ from the town of Chełm. The landscape of the study area is dominated by the Cladietum marisci sedge community, and it is a wetland area. These marshes are produced by karst processes due to the accumulation of organic and mineral matter in hollows in the terrain. Marshes are supplied with water solely from precipitation and runoff from the surrounding hills and fed by groundwater. This marshland is an internationally renowned refuge for birds - protected within the European NATURA 2000 network - as the Chełm Calcareous Marshes [21].

AWs were counted during the first broods from 20 May to 10 June. The counts were done in the evening from 19:30 to $21: 30$, that is, around one hour before sunset and half-an-hour after sunset, in accordance with the methodology for studying this species $[3,7]$. Singing AW male were counted on the survey plot by a team of 6-8 persons who walked along fixed routes separated by a distance of 50-70 m. Observers were equipped with GPS receivers for defining and recording the geographical coordinates of the AW male they encountered. Observers did not approached the males, and only at a distance $>50 \mathrm{~m}$ (the enforced options displaceable point) did they marked the position of the male. This enabled the number of singing males and their distribution on the survey plot to be established. Water levels on the survey plot were measured directly during the AW counts (14-16 readings were taken at randomly selected points), but approximately the same areas were assessed each year. Additionally, the surface water levels were referred to the groundwater levels measured with a piezometer at the Olenówka water gauge (R5T), which is situated at a close $1.3 \mathrm{~km}$ distance by the survey plot. Groundwater levels were measured once a month, and the averages of two readings (temporarily closest to the counting time) were used in calculations.

For this study we applied the GAMM model, taking into account time series and temporal autocorrelation between the number of singing males across the years of observation, and then incorporating the temporal noise in the model procedure. The noise modelling is achieved via a non-separable time-vector autoregressive process. Here we used the MGCV package, and a term based on temporal autocorrelation was added to the model. The structure of the model considers the count of singing males (Poisson distribution) in response to temporal (year of survey) and environmental (level of water) effects. The term based on temporal autocorrelation was defined by the year of the survey.

Correlations between the number of birds and the measurements of water level in the study area were determined by the common non-parametric Spearman rank correla- 


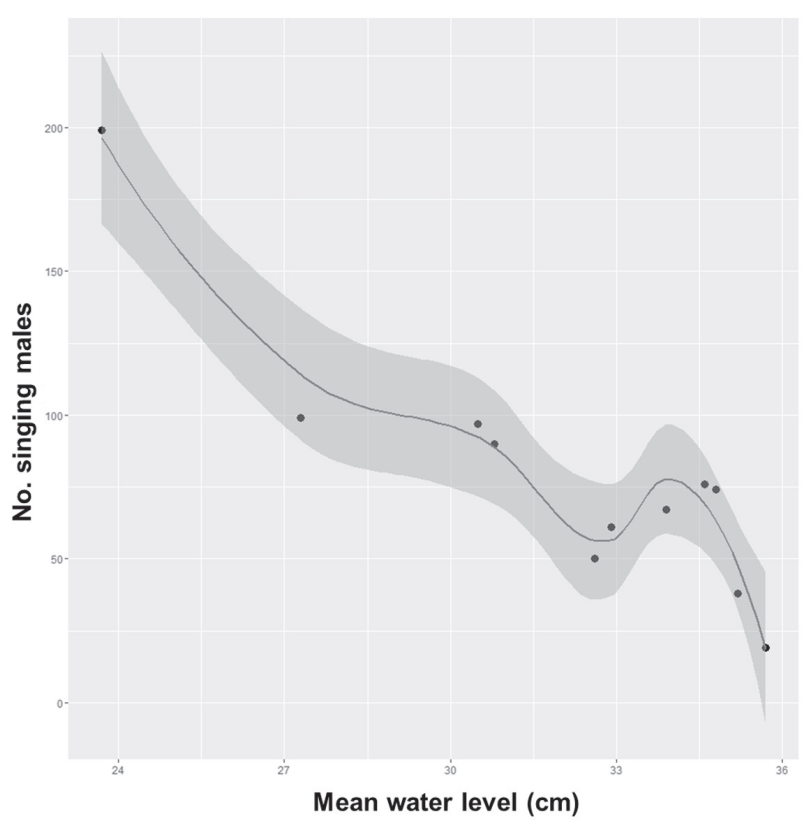

Fig. 1. The plot between the number of singing aquatic warbler males (y-axis) and the level of water $(\mathrm{cm})$ (x-axis). Each point corresponds to a different year. The smooth line (solid line) is the estimate of the number of singing males, and the shadow band around the fitted line corresponds to the confidence intervals.

tion coefficient $\left(\mathrm{r}_{\mathrm{s}}\right)$ [22] using the 'corr.test()' function. All the calculations for determining statistically significant dependency between the considered variables were made using R software [23].

\section{Results and Discussion}

The number of singing AW males varied from 19 (2013) to 199 (2004), with densities from 2.1 to $10.9 \widehat{\delta} \widehat{\delta} / 10$ ha. The mean water level on the survey plot fluctuated between 23.7 and $35.7 \mathrm{~cm}$. The minimum water level $(5-34 \mathrm{~cm})$ was recorded in 2004 and the maximum $(15-55 \mathrm{~cm})$ in 2009 . The greatest variations in measurements were reported in $2008(\mathrm{SE}=3.8 \mathrm{~cm})$ and $2014(\mathrm{SE}=3.7 \mathrm{~cm})$, and the smallest in 2012 $(\mathrm{SE}=1.8 \mathrm{~cm})$ and $2003(\mathrm{SE}=2.58 \mathrm{~cm})$. The changes in number and density of singing males were correlated with the variability of water levels. Analysis of the relationships between the water level on the survey plot and the number of AWs revealed a strong statistically significant negative correlation between these two variables $\left(r_{s}=-0.827, p=0.003\right)$. These results show that increasing water levels are accompanied by decreasing numbers of AWs on the survey plot (Fig. 1). A smaller number of singing males was found during higher water level and the largest number of males was recorded in 2004, when the mean water level was $23.7 \mathrm{~cm}$ (range $5-34 \mathrm{~cm}$ ), and the smallest number of singing males was recorded in 2013, when the mean water level was $35.7 \mathrm{~cm}$ (range 13-52 cm) (Table 1).

Additional data on the water regime on the fen mire during the study period was obtained from piezometer (R5T) readings of the groundwater level. These readings showed that the groundwater depth was negatively correlated with the mean surface water level on the survey plot $\left(r_{s}=-0.809, p=0.004\right)$. This implies that groundwater level can be used as an alternative and simpler method of monitoring the level of surface water. Direct correlation between the groundwater levels and the AW numbers on the fen mire is also strongly significant $\left(r_{s}=0.764\right.$, $\mathrm{p}=0.009$ ).

The results of GAMM model confirm that the number of singing AW males of was strongly correlated with the mean water level $(\mathrm{cm})$. The mean water level was a significant predictor of the number of males singing and the value of the estimate was negative (Table 2).

During the past 100 years, the numbers of AWs has declined heavily both in Europe as a whole [2] and in Poland [4]. In the $19^{\text {th }}$ century, AWs nested practically everywhere in the Polish lowlands, and in large numbers in the Polish part of Polesie [24]. In 2003 the AW population in Poland was estimated at 3,400-3,550 singing males (J. Krogulec and J. Kloskowski, unpublished data). AW counts in Poland yielded 3,154 singing males in 2009 [25] and 3,256 males in 2012 [26]. In the last 20 years, the numbers of AWs have decreased by ca $30 \%$ in the whole

Table 1. Number and density of singing aquatic warbler (AW) males and changes in surface water levels on the survey plot in Roskosz Nature Reserve in 2004-14.

\begin{tabular}{|c|c|c|c|c|c|c|c|c|c|c|c|}
\hline Year of study & 2004 & 2005 & 2006 & 2007 & 2008 & 2009 & 2010 & 2011 & 2012 & 2013 & 2014 \\
\hline $\begin{array}{c}\text { Number of singing AW } \\
\text { males }\end{array}$ & 199 & 97 & 99 & 50 & 74 & 38 & 76 & 61 & 90 & 19 & 67 \\
\hline $\begin{array}{c}\text { Density of singing AW } \\
\text { males / 10 ha }\end{array}$ & 10.9 & 5.3 & 5.4 & 2.7 & 4.1 & 2.1 & 4.2 & 3.3 & 4.9 & 1 & 3.7 \\
\hline Mean water level [cm] & 23.7 & 30.5 & 27.3 & 32.6 & 34.8 & 35.2 & 34.6 & 32.9 & 30.8 & 35.7 & 33.9 \\
\hline Standard error [cm] & 3.34 & 3.15 & 2.58 & 2.87 & 3.80 & 3.38 & 3.28 & 2.83 & 1.80 & 2.98 & 3.70 \\
\hline $\begin{array}{c}\text { Range of changes in water } \\
\text { level [cm] }\end{array}$ & $5-34$ & $8-43$ & $6-38$ & $13-47$ & $9-51$ & $15-55$ & $11-48$ & $11-44$ & $8-35$ & $13-52$ & $7-53$ \\
\hline $\begin{array}{c}\text { Number of measuring } \\
\text { points (N) }\end{array}$ & 14 & 14 & 16 & 15 & 16 & 15 & 15 & 16 & 16 & 16 & 16 \\
\hline
\end{tabular}


Table 2. Parameter estimates of GAMM model explaining the number of singing aquatic warbler males in relation to mean water level. Significant effects are marked with asterisks. Effect of the temporal autocorrelation term (year of observations) was included in the models but is not significant. SE is standard error.

\begin{tabular}{|c|c|c|c|c|}
\hline \multicolumn{5}{|c|}{ Results of GAMM model $(\mathrm{n}=11)$} \\
\hline Variables & Estimate & $\mathrm{SE}$ & $\mathrm{z}$ value & $\mathrm{P}$ \\
\hline (Intercept) & 7.861 & 0.941 & 8.347 & $0.000^{* * *}$ \\
\hline $\begin{array}{c}\text { Mean water } \\
\text { level }\end{array}$ & -0.112 & 0.029 & -3.742 & $0.005^{* *}$ \\
\hline $\begin{array}{c}\text { Approximate } \\
\text { significance } \\
\text { of smooth } \\
\text { term }\end{array}$ & & $\mathrm{F}$ & $\mathrm{P}$ \\
\hline s(year) & & & 0.101 & 0.759 \\
\hline 0.815 & & & \\
\hline
\end{tabular}

Signif. codes: 0 '***' 0.001 '**' 0.01 '*’ 0.05 ', 0.1 ' ' 1

of the Roskosz Nature Reserve (Table 1). The counts done on the survey plot also show quite considerable fluctuations in numbers. In contrast, the state of the whole population inhabiting the Polish part of Polesie appears to be stable with just a $5-10 \%$ drop in numbers (Table 2). The main factors affecting AW numbers, and hence breeding success, are habitat conditions [3, 7-8], predation [8], and food resources [6-7, 27].

The habitat conditions on the fen mires near Chełm are fairly stable, but the water level does change conspicuously. The fluctuations in water level are of a longterm nature, however, without any sudden changes during one breeding season. The mean water level on these fen mires over a period of 11 years (2004-14) varied from 24 to $36 \mathrm{~cm}$. The measured depth of water was greater, and

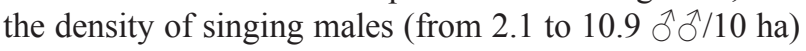
distinctly smaller than the corresponding parameters reported from the Biebrza Marshes [3, 7-8], Belarus [8], and Pomerania [13]. The Polish breeding localities of AW on the Biebrza and Narew are periodically inundated by waters from the two rivers, which reduces the stability of the breeding habitat. Results from the Biebrza Basin indicate that the optimum water level for AW broods in Poland is a few centimetres $(1-10 \mathrm{~cm})$ [7]. The only difference between Cladium marshes and fen mires is that in the investigated Cladium marshes the preferred water level is clearly higher. A higher water level makes this habitat less attractive to AWs. Indeed, when water levels in the Biebrza Valley exceed $20 \mathrm{~cm}$, no singing AW males were found [3]. This dependence was also observed in the Roskosz Nature Reserve. An important aspect for the protection (species conservation planning) of AW is to keep maintaining the aboveground water level to $10 \mathrm{~cm}$. The higher water level limits nesting or makes it even impossible. In the case of Pomeranian breeding areas (Wolin National Park, Rozwarowo Marshes, Lower Oder Valley National Park, Warta Mouth National Park, Karsiborska Kępa, Gryfino), females built their nests in places that are characterized by moist to wet soils (without water above soil surface) [12]. The water level on those areas in late May and early June was only $0.5 \mathrm{~cm}[13]$.

\section{Conservation Implications}

Habitat quality, expressed inter alia by the water level, affects the attractiveness of an area to AWs. Optimal habitat conditions, in combination with abundant food resources and minimal pressure from predators, enable AWs to achieve greater breeding densities. A fairly high breeding AW density was reported from the "Zvanets" reserve in Belarus, where the density of singing males during the first brood was $8.1 \hat{\delta} \delta^{\lambda} / 10$ ha [8]. The water level at this locality in spring is from 20 to $50 \mathrm{~cm}$, but gradually falls as the breeding season progresses. In May and June, when AWs start to breed, the water reaches its optimal level of a few to a dozen or so $\mathrm{cm}[3,8]$. The water level in the breeding locality and its periodic fluctuations are extremely important factors as regards breeding success of AW and other bird species [28-31]. The results from Belarus indicate that sudden changes in water level due to heavy rainfall can cause nests to be flooded and therefore lost [8]. Observations from two other large AW localities in Belarus include Dikoe and Sporovskoe.

Dikoe is an example of a locality where the water level in the breeding habitat depends mainly on rainfall. Normally the water level is near zero, but can rise very quickly following heavy summer rains, and this affects the density of singing males (4.7 $\hat{\delta} / 10 \mathrm{ha})$. This density is lower than that in the Zvanets Reserve, where there are greater fluctuations in water level. Sporovskoe Reserve in the valley of the Yaselda River is dependent on floodwaters from this river, and in the breeding season the water level can change from more than $40 \mathrm{~cm}$ above to $30 \mathrm{~cm}$ below ground level [8]. The density of singing males in such habitat conditions was lower than in the Zvanets Reserve. Changes in water level during the breeding season are potentially detrimental to incubating females, because any significant water rise will flood nests, which are usually built just a small distance above the water level [7, 32]. In such strongly transformed habitat conditions, the chances of species surviving are not very great - especially for a specialised one like AW $[6,27]$. Dynamic changes in habitat combined with falls in numbers have been recorded in the German part of Pomerania [13, 33]. The AWs in that locality moved to wetter sites, abandoning the dry ones.

These results confirm the importance of water as one of the principal habitat factors for this species of bird in calcareous Cladium mariscus fen mires. Our findings are also useful on the study of the niche occupied by the species. In this sense, our results can constitute an important input to the development of more accurate species distribution models (SDMs) [34] for the AWs, and help to understand the potential response of the species facing climatic change scenarios. 
One factor directly associated with habitat moisture levels is the succession of plants - mainly reeds and shrubs. The negative aspect of this process (the overgrowing of open spaces by shrubs and reeds) has been quite widely described [3, 35-36]. One way of halting this succession is to mow the fen mires, which improves the habitat conditions for AW. The results in counts on the survey plot in the Roskosz Nature Reserve that appear to confirm this. After this area was mown in autumn 2011, there was a distinct rise in the number of singing AW males in the following season. Similar effects were observed on the Biebrza [11, 37] and in Polesie National Park [20].

\section{Conclusion}

The number of AWs was correlated with the mean water level and with the mean ground water level. We found that the higher the surface water level, the smaller the number of singing males. These results can be useful in the studies focused on the optimal habitat conditions for AW breeding.

Water levels in breeding localities and their periodic fluctuations are extremely important factors as regards breeding success. Changes in water level during the breeding season are potentially detrimental to incubating females, because any significant rise can flood nests, which are usually built just a small distance above the water level. In such strongly transformed habitat conditions, the chances of species survival are not very great - especially for a specialised one like AW.

These results confirm the importance of water as one of the principal habitat factors for this species of bird. Our findings are also useful on the study of the niche occupied by the species. In this sense, our results can constitute an important input to the development of more accurate species distribution models and help to understand the potential response of the species facing climatic change scenarios.

\section{Acknowledgements}

We would like to thank all the persons who helped us count AWs, namely: E. Dżaman, D. Baranowska-Kobus, M. Bednarczyk, Ł. Bernacki, P. Bierdziński, R. Bochen, M. Bojarczuk, Sz. Cios, K. Czuryło, S. Czyżowicz, G. Debejdka, E. Dziedzicka, P. Farjan, J. Fornal, T. Gąsior, M. Goc, K. Grabarczuk, W. Gustaw, G. Janek, K. Król, B. Kusal, K. Łapińska, S. Łubkowska, K. Łubkowski, A. Małkiewicz, M. Mamełka, P. Mazurek, M. Michałek, A. Misztal, W. Namolnik, K. Nitek, Ł. Nowacki, K. Opat, P. Oziemczuk, K. Pawłowski, A. Petruk, G. Potakiewicz, P. Radomski, P. Romaniuk, D. Rosiński, A. Różycki, E. Rudzińska, M. Smoleń, A. Smolińska, K. Stepach, M. Stróżek, T. Stróżek, Ł. Sulima, M. Sułecki, P. Szczepaniak, K. Szulak, M. Szymczuk, M. Tkaczyk, A. Wałek, R. Wereski, R. Wiśniewski, M. Władyka, K. Włosek, P. Woć, B. Wołczuk, Wójcik, R. Wróblewski, B. Wrzochal,
I. Zaborek, K. Zagraba, M. Zajdel, S. Zaklika, S. Zgorzałek, B. Zienkiewicz, D. Żołnowska, A. Żuchnik.

Apart from this, the monitoring was done within the framework of projects implemented by the Polish Society for the Protection of Birds: EU LIFE Project "Conserving Acrocephalus paludicola in Poland and Germany" (LIFE05 NAT/PL/000101) and EU LIFE+ "Facilitating Aquatic Warbler (Acrocephalus paludicola) habitat management through sustainable systems of biomass use" (LIFE09 NAT/PL/000260).

\section{References}

1. BIRDLIFE INTERNATIONAL. Species factsheet: Acrocephalus paludicola. Available at: www.birdlife.org. IUCN 2013. IUCN Red List of Threatened Species. Version 2013.2. Web: www.iucnredlist.org, Accessed 26 June 2013.

2. FLADE M., LACHMANN L. International species action plan for the Aquatic Warbler Acrocephalus paludicola. Cambridge, UK: BirdLife International. 2008.

3. KLOSKOWSKI J., KROGULEC J. Habitat selection of Aquatic Warbler Acrocephalus paludicola in Poland: consequences for conservation of the breeding areas. Vogelwelt. 120, 113, 1999

4. TOMIAŁOJĆ L., STAWARCZYK T. The Avifauna of Poland. Distribution, numbers and trends. PTPP „proNatura”, 870, 2003 [In Polish].

5. WÓJCIAK J., BIADUŃ W., BUCZEK T., PIOTROWSKA $\mathrm{M}$. The atlas breeding birds of Lublin region. LTO, Lublin 314, 2005 [In Polish].

6. SCHULZE-HAGEN K. Acrocephalus paludicola (Vieillot 1817) - Seggenrohrsänger. In: Glutz von Blotzheim U.N. (Eds.) Handbuch der Vögel Mitteleuropas. Vol. 12/I. Wiesbaden: Aula. 1991

7. DYRCZ A., ZDUNEK W. Breeding ecology of the Aquatic Warbler Acrocephalus paludicola on the Biebrza marshes, northeast Poland. Ibis. 135, 181, 1993.

8. VERGEICHIK L., KOZULIN A. Breeding ecology of Aquatic warblers Acrocephalus paludicola in their key habitats in SW Belarus. Acta Ornithol. 41, 153, 2006.

9. TANNEBERGER F., BELLEBAUM J., FARTMANN T., HAFERLAND H.J., HELMECKE A., JEHLE P. Rapid deterioration of Aquatic Warbler Acrocephalus paludicola habitats at the western margin of the breeding range. J. Orn. 149, 105, 2008.

10. AQUATIC WARBLER CONSERVATION TEAM. World population, trends and conservation status of the Aquatic Warbler Acrocephalus paludicola. Vogelwelt. 120, 65, 1999.

11. KUBACKA J., OPPEL S., DYRCZ A., LACHMANN L. BARROS DA COSTA J.P.D., KAIL U., ZDUNEK W. Effect of mowing on productivity of the endangered Aquatic Warbler Acrocephalus paludicola. Bird Conserv. Int. 24, 45, 2013.

12. TANNEBERGER F., BELLEBAUM J., HELMECKE A., MINETS M. Nesting and foraging characteristics of Aquatic warblers Acrocephalus paludicola in the fast declining Pomeranian population (NE Germany/NW Poland). Acta Ornithol. 48, 109, 2013.

13. TANNEBERGER F., FLADE M., PREIKSA Z., SCHRODER B. Habitat selection of the globally threatened Aquatic Warbler Acrocephalus paludicola at the western margin of its breeding range and implications for management. Ibis. 152, 347, 2010. 
14. TANNEBERGER F., TEGETMEYER C., DYLAWERSKI M., FLADE M., JOOSTEN H. Commercially cut reed as a new and sustainable habitat for the globally threatened Aquatic Warbler. Biodivers. Conserv. 18, 1475, 2009.

15. DYRCZ A., ZDUNEK W., SCHULZE-HAGEN K. Increased male singing in response to predator presence may represent reproductive investment in a promiscuous species, the Aquatic Warbler Acrocephalus paludicola. Acta Ornithol. 46, 97, 2011.

16. OPPEL S., MARCZAKIEWICZ P., LACHMANN L., GRZYWACZEWSKI G. Improving Aquatic Warbler Population Assessments by Accounting for Imperfect Detection. PLOS ONE 9:e94406. doi:10.1371/journal.pone.0094406. 2014.

17. GRZYWACZEWSKI G., CIOS SZ., SPARKS T.H., BUCZEK A., TRYJANOWSKI P. Effect of habitat burning on the number of singing males of the Aquatic Warbler Acrocephalus paludicola. Acta Ornithol. 49, 175, 2014.

18. GRZYWACZEWSKI G., OSIEJUK T.S., CIOS SZ., MARCZAKIEWICZ P. Song post selection in the aquatic warbler Acrocephalus paludicola. Ann. Zool. Fenn. 51, 495, 2014.

19. KLOSKOWSKI J., TANNEBERGER F., MARCZAKIEWICZ P., WIŚNIEWSKA A., CHOYNOWSKA A. Optimal habitat conditions for the globally threatened Aquatic Warbler Acrocephalus paludicola in eastern Poland and their implications for fen management. Ibis. 157, 406, 2015.

20. GRZYWACZEWSKI G. Long-term changes number of Aquatic Warlbrel Acrocephalus paludicola in Poleski National Park in the context of extensive agricultural use. Annales UMCS section EE. 33, 1, 2015.

21. WILK T., JUJKA M. KROGULEC J., CHYLARECKI P. Important Bird Areas of international importance in Poland. OTOP, Marki. 2010.

22. HOLLANDER M., WOLFE D.A. Nonparametric Statistical Methods. Second Edition. New York: John Wiley and Sons. 1999.

23. R CORE TEAM. R: A language and environment for statistical computing. R Foundation for Statistical Computing, Vienna, Austria. ISBN 3-900051-07-0, URL www.R-project.org, 2016.

24. TACZANOWSKI W. Polish birds. Krakow, 125, 1882 [In Polish].

25. MANIAKOWSKI M. The overall inventory of the Aquatic Warbler Acrocephalus paludicola in 2009. Ptaki. 4, 16, 2009 [In Polish].
26. ZADRĄG M. Inventory of Aquatic warblers in Poland in 2012. Research report. The Polish Society for the Protection of Birds (OTOP), Marki. www.otop.org.pl/uploads/media/ raport_wodniczka_2012, 2012 [In Polish]..

27. LEISLER B., LEY H.W., WINKLER H. Habitat behaviour and morphology of Acrocephalus Warblers: an integrated analysis. Ornis. Scand. 20, 181, 1989.

28. POLAK M. Nest site selection and nest predation in the Great Bittern Botaurus stellaris population in eastern Poland. Bird Study. 54, 280, 2007.

29. POLAK M., KASPRZYKOWSKI Z., KUCHARCZYK M. Micro-habitat nest preferences in the Great Bittern Botaurus stellaris on fishponds in central-eastern Poland. Ann. Zool. Fenn. 45, 102, 2008.

30. WIACCEK J. Benefits and costs of semi-colonial breeding in Montagu's harrier Circus pygargus. Belg. J. Zool. 138, 36, 2008.

31. WIĄCEK J. Nest site selection of Montagu's Harrier Circus pygargus breeding in natural habitats in eastern Poland. Ardea. 97, 117, 2009.

32. KOZULIN A., FLADE M. Breeding habitat abundance and conservation status of the Aquatic Warbler Acrocephalus paludicola in Belarus. Vogelwelt. 120, 97, 1999.

33. FRICK A., TANNEBERGER F., BELLEBAUM J. ModelBased Selection of Areas for the Restoration of Acrocephalus paludicola Habitats in NE Germany. Environ. Manage. 53, 728, 2014.

34. ELITH J., GRAHAM C.H. Do they? How do they? WHY do they differ? On finding reasons for differing performances of species distribution models. Ecography. 32, 66, 2009.

35. LACHMANN L., MARCZAKIEWICZ P., GRZYWACZEWSKI G. Protecting Aquatic warblers (Acrocephalus paludicola) through a landscape-scale solution for the management of fen peat meadows in Poland. Grassland Sci. Eur. 15, 711, 2010.

36. KOTOWSKI W., JABŁOŃSKA E., BARTOSZUK H. Conservation management in fens: Do large tracked mowers impact functional plant diversity. Biol. Conserv. 167, 292, 2013.

37. GRYGORUK M., BATELAAN O., MIROSŁAWŚWIĄTEK D., SZATYŁOWICZ J., OKRUSZKO T. Evapotranspiration of bush encroachments on a temperate mire meadow - a nonlinear function of landscape composition and groundwater flow. Ecol. Eng. 73, 598, 2014. 